\title{
PARTISIPASI MASYARAKAT DALAM MENDUKUNG PELAKSANAAN PROGRAM SEKOLAH
}

\author{
Renny Retna Puspasari \\ SMP Islam Al-Akbar Singosari, Jl. Diponegoro Ardimulyo Singosari \\ E-mail: rennyretna@gmail.com
}

\begin{abstract}
This research are describe about community participation in supporting the implementation of school programs at KB-TK Al Falah Batu. The methods of research used the qualitative approach and the type of case study research. Data collection techniques using interview techniques, observation, and documentation. Data analysis using data reduction, data display, and verification of data. Checking the validity of the data using triangulation, member check, increases perseverance, and completeness reference. The results of this research are community that was given participation in school programs implementation are parents, organization community, and general community. The participation are about idea, energy, financial, and infrastructure.
\end{abstract}

Keyword: participation, community, school programs.

\begin{abstract}
Abstrak: Penelitian ini mendeskripsikan partisipasi masyarakat dalam mendukung pelaksanaan program sekolah. Penelitian ini menggunakan pendekatan kualitatif dengan jenis studi kasus. Teknik pengumpulan data menggunakan wawancara, observasi, dan dokumentasi. Pengecekan keabsahan data menggunakan triangulasi, pengecekan anggota, meningkatkan ketekunan, dan kecukupan bahan referensi. Hasil dari penelitian ini yaitu masyarakat yang berpartisipasi dalam pelaksanaan program sekolah ialah orang tua murid, masyarakat terorganisasi, dan masyarakat umum. Partisipasi yang diberikan berupa gagasan, tenaga, materi, serta sarana dan prasarana.
\end{abstract}

Kata kunci: partisipasi, masyarakat, program sekolah.

Penyelenggaraan pendidikan akan berjalan secara maksimal apabila terdapat kerjasama yang baik dari berbagai pihak, yaitu pemerintah, keluarga, dan masyarakat. Adanya partisipasi dan dukungan dari masyarakat sangat penting dalam memperlancar proses pencapaian tujuan pendidikan. Triwiyanto dan Kusumaningrum (2015:5) menyatakan bahwa terdapat hubungan antara alasan penting dan upaya membangun harmoni kerja sekolah dan komite sekolah. Partisipasi dari masyarakat ini bergantung pada bagaimana suatu lembaga menjalin hubungan dan kerjasama yang baik dengan masyarakat sehingga partisipasi yang diberikan oleh masyarakat bisa maksimal. Lembaga yang mampu menjalin hubungan dan kerja sama yang baik dengan masyarakat akan menimbulkan citra lembaga yang baik di mata masyarakat, sehingga ketika lembaga membutuhkan dukungan dan partisipasi mereka, masyarakat akan dengan sukarela memberikan partisipasinya demi mencapai tujuan bersama. Dalam penyelenggaraan pendidikan di sekolah, adanya dewan sekolah juga diperlukan dalam mendukung pencapaian tujuan pendidikan. Terbentuknya dewan sekolah, sekolah lebih mudah berkoordinasi dan bekerjasama dalam rangka mencapai tujuan pendidikan. Keberhasilan dewan sekolah ditentukan oleh bagaimana dewan sekolah dalam melakukan kerjasama dengan sekolah. Penelitian yang dilakukan oleh Benjamin dan Chui (1997) menemukan "beberapa faktor yang terkait dengan keberhasilan dewan sekolah yaitu: kesiapan dan penerimaan timbal balik antara orang tua dan guru, komitmen pokok, kepuasan orang tua dengan partisipasi yang mereka berikan, dan kontribusi orang tua serta sumbangan untuk sekolah.

Partisipasi masyarakat merupakan suatu bentuk keterlibatan masyarakat dalam suatu kegiatan yang dalam lingkungkan pendidikan 
yaitu keterlibatan dalam penyelenggaraan pendidikan di sekolah baik itu dalam perencanaan, pelaksanaan, maupun evaluasi. Menurut Sumarto (2004:188) "partisipasi sering diberi makna keterlibatan orang secara sukarela tanpa tekanan dan jauh dari perintah. Partisipasi dapat dilakukan mulai tahap perumusan kebijakan dan penyusunan rencana, tahap implementasi sampai tahap pemantauan dan evaluasi“. Partisipasi yang diberikan masyarakat tidak harus berupa materi, tetapi juga bisa partisipasi dengan menyumbangkan tenaga dan pikiran. Penyelenggaraan pendidikan di sekolah, orang tua mempunyai peranan yang sangat penting dalam mendukung berjalannya pendidikan di sekolah. Berdasarkan temuan penelitian yang dilakukan Shun (2013) ada empat fase perkembangan bagaimana orang tua termasuk dalam tata kelola sekolah yaitu orang tua sebagai tamu tak diundang yang berarti mereka datang ke sekolah untuk mendaftarkan anaknya ke sekolah; orang tua sebagai relawan (berpartisipasi); orang tua sebagai klien yaitu kerja sama yang dilakukan antara pihak sekolah dengan orang tua berkaitan dengan pendidikan anak; dan orang tua sebagai gubernur sekolah yang mempunyai tanggung jawab terhadap penyelenggaraan pendidikan di sekolah.

Lembaga pendidikan Al-Falah memiliki 2 program pendidikan yaitu Kelompok Bermain (KB) dan Taman Kanak-kanak (TK). Untuk mendukung keberhasilan program sekolah, lembaga pendidikan ini sering sekali melibatkan masyarakat dalam pelaksanaan program sekolah baik itu orang tua, lembaga pemerintahan, maupun masyarakat pada umumnya. Lembaga pendidikan Al-Falah merupakan lembaga pendidikan yang terkenal memiliki programprogram yang inovatif. Sekolah selalu berupaya untuk menciptakan suasana belajar yang menyenangkan dengan kegiatan-kegiatan yang diberikan kepada peserta didik di sekolah. Keunikan dari program-program kegiatan yang dilakukan di sekolah ini yaitu sekolah selalu mengaplikasikan kegiatan pembelajaran dalam bentuk yang nyata dengan melibatkan pihakpihak tertentu untuk mendukung keberhasilan program sekolah. Pelaksanaan programprogram di lembaga ini, masyarakat yang sering terlibat dalam kegiatannya yaitu orang tua murid. Berdasarkan konteks penelitian di atas peneliti mengambil 4 fokus penelitian yaitu 1) perencanaan program sekolah di KB-TK Al Falah Batu, 2) teknik peningkatan partisipasi masyarakat dalam mendukung pelaksanaan program sekolah di KB-TK Al Falah Batu, 3) faktor pendukung dan penghambat partisipasi masyarakat dalam pelaksanaan program sekolah di KB-TK Al Falah Batu, dan 4) upaya mengatasi hambatan partisipasi masyarakat dalam mendukung pelaksanaan program sekolah di KBTK Al Falah Batu.

\section{METODE}

Penelitian ini menggunakan pendekatan kualitatif, menurut Moleong (2012:6) "penelitian kualitatif adalah penelitian yang bermaksud untuk memahami fenomena tentang apa yang dialami oleh subyek penelitian secara holistik dengan cara deskripsi, pada suatu konteks khusus yang alamiah dan dengan memanfaatkan berbagai metode ilmiah. Pendekatan kualitatif ini dipilih karena fokus yang diteliti lebih banyak membahas cara dan memerlukan observasi atau pengamatan dalam situasi sebenarnya. Dalam hal ini peneliti melakukan pengamatan dengan melihat situasi sebenarnya yang terjadi dilapangan. Jenis penelitian studi kasus yaitu untuk mengetahui bagaimana partisipasi masyarakat dalam mendukung pelaksanaan program sekolah di KB-TK Al Falah Batu. Peneliti hadir di lokasi penelitian untuk mengumpulkan data dan menciptakan hubungan baik dengan subjek penelitian. Lokasi penelitian di J1. Raya Panglima Sudirman RT 02 RW 06 Desa Tlekung Kecamatan Junrejo Kota Batu. Penggalian data dilakukan melalui informan yang telah ditentukan yaitu kepala KB-TK Al Falah Batu, guru, advisor, bendahara, pembina ekstrakurukiler drum band dan sepak bola serta orang tua murid. Pengumpulan data dilakukan dengan menggunakan teknik wawancara, observasi, dan dokumentasi. Teknik wawancara dilakukan secara face to face dengan mengajukan pertanyaan berdasarkan pedoman yang telah dibuat sebelumnya. Observasi dilakukan dengan mengamati kegiatan-kegiatan yang berhubungan dengan judul penelitian. Sedangkan untuk teknik dokumentasi peneliti mendokumentasikan kegiatan-kegiatan yang dilakukan di KB-TK Al Falah Batu baik kegiatan yang diamati langsung maupun dokumentasi yang dimiliki oleh sekolah. 
Data yang diperoleh kemudian dianalisis melalui proses reduksi, penyajian data, dan penarikan kesimpulan.

Untuk pengecekan keabsahan data dilakukan dengan menggunakan triangulasi data, pengecekan anggota, meningkatkan ketekunan, serta kecukupan bahan referensi. Triangulasi yang digunakan yaitu triangulasi sumber dan teknik. Triangulasi sumber dilakukan dengan mengecek data dari tiga informan yang berbedabeda. Sedangkan triangulasi teknik dilakukan dengan mengecek data melalui 3 teknik yang berbeda yaitu melalui wawancara, observasi, dan dokumentasi. Data yang diperoleh berdasarkan hasil wawancara yang telah di catat dalam transkrip wawancara kemudian dikonfirmasikan kembali ke informan yang bersangkutan (member check). Peneliti menggunakan ketekunan pengamatan untuk mengetahui keakuratan data yang diperoleh. Untuk mendukung semua data yang diperoleh digunakan bahan referensi yang cukup untuk membuktikan data yang ditemukan. Bahan-bahan itu antara lain transkrip wawancara yang disusun berdasarkan hasil wawancara yang dilakukan ke beberapa informan, catatan lapangan hasil observasi, alat bantu rekam untuk merekam informasi-informasi yang diperoleh dari informan dan merekam kegiatan-kegiatan yang diamati, serta foto-foto kegiatan baik yang didokumentasikan oleh peneliti sendiri maupun foto-foto kegiatan yang diberikan oleh informan. Penelitian ini dilakukan melalui beberapa tahapan penelitian antara lain tahap pendahuluan yaitu dengan melakukan studi pendahuluan di KB TK Al Falah Batu, tahap pelaksanaan penelitian, dan tahap penyusunan laporan penelitian.

\section{HASIL}

Perencanaan program sekolah di KB-TK Al Falah Batu yaitu melakukan evaluasi program kegiatan tahun lalu dalam kegiatan rapat kerja (raker) yang diikuti oleh semua pendidik dan tenaga kependidikan di KB-TK Al-Falah Batu. Dari hasil eveluasi tersebut dilihat kelebihan dan kekurangan dari masing-masing program kegiatan yang sudah dijalankan tahun lalu. Setelah itu barulah menentukan program kerja dengan menyeleksi program-program dari hasil evaluasi dengan berbagai pertimbangan yaitu melihat situasi dan kondisi yang memungkin- kan program tersebut untuk dijalankan. Adapun prosedur program-program kegiatan yang akan dilakukan mengacu pada SOP yang sudah ada. Setelah program kerja tersusun ditentukan penjadwalan untuk masing-masing program kegiatan yang akan dilakukan yaitu kegiatan mana yang didahulukan dan kegiatan mana yang dilakukan diakhir. Langkah selanjutnya ialah menentukan anggaran biaya untuk masing-masing program yang akan dijalankan. Kepala KB TK Al Falah membentuk penanggungjawab untuk masingmasing program kegiatan yang ditugaskan kepada semua pendidik dan tenaga kependidikan di TK Al Falah Batu. Penanggung jawab disini bertugas untuk mengurus segala hal yang berkaitan dengan program kegiatan yang akan dilakukan, setelah semua program kerja tersusun dan disepakati bersama barulah dicetak dalam kalender akademik. Setelah itu pihak sekolah menyampaikan semua program kegiatan kepada orang tua murid untuk berkoordinasi mengenai program kegiatan yang akan dilakukan selama satu tahun kedepan. Pertemuan orang tua murid memberikan saran dan masukan terhadap program kegiatan yang akan dilaksanakan.

Teknik peningkatan partisipasi masyarakat dalam mendukung pelaksanaan program sekolah di KB-TK Al Falah Batu yaitu dengan melibatkan masyarakat dalam setiap program kegiatan yang dilakukan sekolah. Program kegiatan tersebut yaitu program kegiatan puncak tema, kegiatan market day, kegiatan home visit, kegiatan ekstrakurikuler (sepak bola dan drum band), kegiatan PHBI dan PHBN, program Usaha Kesehatan Sekolah (UKS), kegiatan manasik haji, dan kegiatan makan bersama setiap seminggu sekali yang disediakan orang tua murid. Adapun masyarakat yang terlibat dalam mendukung pelaksanaan program kegiatan sekolah antara lain orang tua murid, masyarakat sekitar sekolah, lembaga pendidikan lain yang ikut bergabung dalam pelaksanaan manasik haji, pihak Kementerian Agama yang memberikan pembinaan pada saat kegiatan manasik haji, petugas puskesmas yang memeriksa kesehatan anak secara rutin, dan instansiinstansi yang pernah dilibatkan dalam kegiatan puncak tema antara lain petugas pemadam kebakaran, PUSDIK, kepolisian, stasiun TV ATV, dan pihak wisata kampung sapi. Bentuk partisipasi masyarakat di KB-TK Al Falah Batu yaitu orang tua berpartisipasi sebagai pengisi materi 
pada saat kegiatan puncak tema, membantu pendanaan, sarana, dan juga tenaga pada saat pelaksanaan kegiatan, secara bergiliran orang tua juga bergantian memberikan makanan sehat kepada anak-anak setiap minggu, masyarakat yang diundang sekolah seperti pemadam kebakaran berpartisipasi dalam memberikan pembelajaran secara langsung kepada anak-anak. Pada saat kegiatan manasik haji pihak sekolah juga melibatkan kementrian agama untuk memberikan pembinaan terhadap semua pendidik dan tenaga kependidikan yang ada di KB-TK Al Falah Batu dan juga mengundang lembaga pendidikan lain untuk turut serta bergabung dalam kegiatan, masyarakat sekitar berpartisipasi dalam memberikan bantuan sarana dan tenaga untuk pelaksanaan kegiatan, misalnya pada saat ada event-event di sekolah, pihak balai desa turut membantu untuk menyediakan area parkir dan petugas keamanan, selain itu pada saat kegiatan perpisahan pihak balai desa setempat juga diundang untuk memberikan sambutan-sambutan. Teknik yang kedua yaitu dengan memberikan layanan pembinaan kepada orang tua melalui kegiatan parenting yang dilakukan setiap bulan dengan mendatangkan pemateri dari luar berkaitan dengan pendidikan anak. Dalam kegiatan ini orang tua murid bisa mendapatkan pembinaan dan bimbingan berkaitan dengan cara mendidik anak sehingga akan menumbuhkan kesadaran orang tua tentang pentingnya pendidikan bagi anak dan juga pentingnya partisipasi orang tua dalam penyelenggaraan pendidikan. Teknik yang ketiga yaitu dengan melakukan sosialisasi kepada orang tua murid di setiap pertemuan wali murid dan melakukan pendekatan dengan berkunjung kerumah peserta didik diawal tahun yang ditujukan untuk melakukan observasi kepada calon peserta didik dan mengakrabkan hubungan antara sekolah dan orang tua. Untuk masyarakat sekitar pihak sekolah selalu menjalin hubungan baik misalnya pada saat hari raya pihak sekolah juga berkeliling kerumah-rumah warga, selain itu ketika dimintai partisipasi oleh warga desa, pihak sekolah juga selalu membantu sehingga pada saat pihak sekolah membutuhkan bantuan mereka, mereka juga dengan senang hati membantu sekolah. Teknik yang keempat yaitu dengan memberdayakan POM untuk memberikan motivasi dan mengajak orang tua lain yang kurang berperan aktif sehingga dapat berpartisipasi dalam mendukung pelaksanaan program sekolah. Adapun media yang digunakan sekolah dalam melakukan komunikasi dengan masyarakat untuk mengajak masyarakat berpartisipasi dalam kegiatan sekolah selain mengadakan pertemuan langsung ialah melalui media elektronik dan media cetak antara lain dengan cara memberikan undangan, proposal, informasi melalui buku penghubung siswa, telepon, dan media sosial.

Faktor pendukung partisipasi masyarakat di KB-TK Al Falah Batu yaitu terdiri dari pihak internal dan eksternal. Dari pihak internal yaitu adanya dukungan dari ketua yayasan untuk setiap program yang dijalankan serta semua pendidik dan tenaga kependidikan yang selalu bekerja keras dalam upaya mensukseskan kegiatan dan selalu berupaya dalam menjalin hubungan baik dengan masyarakat baik orang tua murid, tersedianya dana yang mencukupi karena semua anggaran untuk masing-masing kegiatan yang dilakukan dalam satu tahun ajaran sudah dibayarkan diawal tahun, sehingga tidak ada kesulitan dana untuk kegiatankegiatan yang melibatkan masyarakat, serta adanya sarana dan prasarana yang memadai yang dimiliki sekolah sehingga setiap kegiatan yang dilakukan bisa dilaksanakan di sekolah. Pihak eksternal yaitu adanya dukungan dari masyarakat baik orang tua, warga sekitar, dan masyarakat mengenai program kegiatan yang dilakukan di sekolah, sehingga mereka mau memberikan partisipasinya dalam mensukseskan program kegiatan yang dilakukan di sekolah. Sedangkan faktor penghambat partisipasi masyarakat dalam pelaksanaan program sekolah di KB-TK Al Falah Batu antara lain: a) faktor penghambat dari orang tua murid yaitu sulitnya menentukan waktu pelaksanaan kegiatan karena kesibukan pekerjaan orang tua. Selain itu tipe orang tua yang berbeda-beda yaiti tidak semua orang tua berperan aktif dalam mendukung pelaksanaan program sekolah, b) Faktor penghambat dari pihak instansi terkait yang akan dilibatkan dalam kegiatan yaitu kesibukan dari pihak instansi sendiri. Jadi pihak yang dimintai tolong tidak bisa berpartisipasi mengisi kegiatan di sekolah karena kesibukan pihak instansi sendiri. Selain itu sulitnya birokrasi dan adanya tuntutan dari pihak instansi yang tidak memungkinkan untuk sekolah mengikutinya, membuat pihak sekolah tidak bisa melibatkan mereka dalam kegiatan di sekolah. 
Upaya untuk mengatasi hambatan-hambatan yang timbul dari partisipasi masyarakat diatas ialah menentukan waktu yang tepat untuk pelaksanaan kegiatan yang melibatkan masyarakat (orang tua) dengan cara berkoordinasi dengan mereka menentukan waktu yang tepat untuk melaksanakan kegiatan sehingga masyarakat bisa hadir dan berpartisipasi dalam mendukung pelaksanaan program kegiatan di sekolah, pihak sekolah memberdayakan POM (Persatuan Orang Tua Murid) untuk memberikan pengertian dan dorongan kepada orang tua murid lainnya yang tidak mau berpartisipasi agar mereka mau membantu sekolah dengan memberikan partisipasinya pada saat pelaksanaan program kegiatan di sekolah, diawal tahun pihak sekolah sudah mempersiapkan dua pilihan instansi yang akan dituju untu mengisi kegiatan di sekolah, sehingga jika pihak yang satu tidak bisa mengisi karena kesibukan pihak instansi sendiri, maka pihak sekolah bisa menggunakan alternatif yang kedua yaitu dengan mencari pemateri lain pihak sekolah melakukan simulasi sendiri sesuai dengan tema kegiatan yang akan dilakukan.

\section{PEMBAHASAN}

Perencanaan program sekolah di KB-TK Al Falah Batu dilakukan dengan kegiatan evaluasi program tahun lalu dalam kegiatan rapat kerja yang diikuti oleh semua pendidik dan tenaga kependidikan di KB-TK Al Falah Batu. Hasil evaluasi tersebut ditentukan program kegiatan yang akan dilaksanakan tahun mendatang dengan berbagai pertimbangan menyesuaikan dengan situasi dan kondisi yang ada. Setelah program tersusun barulah menentukan penjadwalan untuk masing-masing program dengan menentukan skala priortitas yaitu program mana yang didahulukan dan program mana yang diakhirkan. Setelah dilakukan penjadwalan langkah selanjutnya ialah menentukan anggaran biaya untuk setiap program kegiatan yang akan dilasanakan. Kemudian setelah semuanya tersusun, program kegiatan tersebut dicetak dalam kalender akademik dan disosialisasikan kepada orang tua murid untuk mendapatkan saran dan masukan terhadap program kegiatan yang akan dilaksanakan. Berdasarkan tahapan perencanaan program sekolah yang dilakukan di KB-TK Al Falah Batu sesuai dengan pendapat
Pidarta (1998:213) yang menyebutkan bahwa ada sejumlah langkah perencanaan pendidikan berbasis sekolah yaitu (1) forcasting (prakiraan), (2) objectives (sasaran), (3) policy (kebijakan), (4) programming (pemrograman), (5) procedure (tata cara), (6) schedule (penjadwalan) dan (7) budgeting (pembiayaan).

Teknik peningkatan partisipasi masyarakat dalam mendukung pelaksanaan program sekolah ialah dengan cara sekolah berusaha melibatkan masyarakat dalam setiap program kegiatan yang dilakukan sekolah. Hal ini sesuai dengan pendapat Maisyaroh (2001:115) yang menyatakan bahwa teknik yang cukup efektif dalam berkomunikasi untuk meningkatkan peran masyarakat dan swasta yaitu menggunakan telepon, internet, faksimil, dan sebagainya. Bila menggunakan pendekatan budaya, maka proses sosialisasi yang peru ditempuh, yaitu lembaga pendidikan mengupayakan agar masyarakat mengetahui, mengenal, meyakini, mempercayai, dan merasa perlu pendidikan yang berkualitas.

Faktor pendukung partisipasi masyarakat di KB-TK Al Falah Batu yaitu adanya dukungan dari pihak internal baik ketua yayasan, semua pendidik dan tenaga kependidikan beserta karyawan yang telah bekerja keras dalam mensukseskan kegiatan di sekolah demi tercapainya tujuan sekolah. Selain itu pihak orang tua yang selalu mendukung kegiatan-kegiatan yang dilakukan sekolah, sehingga mereka mau memberikan partisipasinya untuk membantu kegiatan disekolah. Hal ini didasari oleh kepentingan dan rasa solidaritas yang timbul antar orang tua terhadap sekolah. Mereka tentunya menginginkan anaknya berhasil dalam menempuh pendidikan di sekolah, sehingga mereka mau memberikan partisipasinya untuk membantu kegiatan di sekolah demi keberhasilan pembelajaran anak di sekolah. Hal ini sesuai dengan pendapat Sumarto (2004:188) yang menyatakan bahwa faktor pendukung partisipasi masyarakat yaitu (1) kepentingan, yaitu adanya kepentingan tertentu dari seseorang; (2) solidaritas, rasa solidaritas yang tinggi akan mendorong seseorang untuk ikut aktif dan berpartisipasi dalam menjalankan suatu program tertentu; dan (3) tujuan yang sama, partisipasi dan keaktifan seseorang dalam kegiatan tertentu dapat didorong dengan adanya tujuan yang sama. Sedangkan faktor penghambat partisipasi masyarakat di KB-TK Al Falah 
Batu yaitu tipe masyarakat (orang tua) yang berbeda-beda. Setiap orang pasti mempunyai karakteristik yang berbeda-beda. Bersedianya masyarakat untuk ikut berpartisipasi tergantung dari kemauan masyarakat itu sendiri. Kemauan dapat diartikan sebagai usaha aktif menuju suatu tujuan (Mustiningsih, 2009:31). Jika masyarakat yang memiliki kemauan yang tinggi untuk melakukan suatu perubahan, tentunya masyarakat tersebut akan memberikan partisipasinya demi mendukung keberhasilan program sekolah, tapi masyarakat yang memang cenderung tidak peduli terhadap suatu hal, maka mereka juga akan malas memberikan partisipasinya dalam kegiatan di sekolah. Oleh karena itu kemauan timbul dari diri individu itu sendiri. Seseorang yang memiliki kemauan untuk melakukan perubahan tentunya akan bertindak demi tercapainya tujuan yang diinginkan.

\section{KESIMPULAN DAN SARAN}

\section{Kesimpulan}

Berdasarkan hasil analisis dan pembahasan, diperolehempatkesimpulanyaitu(1) langkah awal perencanaan program yaitu dengan melakukan kegiatan evaluasi program kegiatan tahun lalu, menyusun program tahun ajaran baru, menentukan penjadwalan, dan menentukan anggaran biaya untuk setiap program yang akan dijalankan, (2) teknik peningkatan partisipasi masyarakat di KB-TK Al-Falah Batu yang pertama dilakukan dengan cara melibatkan masyarakat dalam setiap program kegiatan sekolah. Teknik yang kedua yaitu dengan memberikan layanan pembinaan kepada orang tua melalui kegiatan parenting. Teknik yang ketiga yaitu dengan cara sosialisasi yang dilakukan pihak sekolah setiap pertemuan wali murid dan melakukan kunjungan kerumah peserta didik di awal tahun. Teknik yang keempat yaitu memberdayakan organisasi Persatuan Orang Tua Murid (POM) untuk memotivasi dan mengajak orang tua lain yang kurang berperan aktif dalam mendukung pelaksanaan program sekolah. Adapun komunikasi yang dilakukan pihak sekolah dengan masyarakat yaitu melalui media elektronik dan media cetak, (3) faktor pendukung partisipasi masyarakat yaitu terdiri dari pihak internal dan eksternal. Dari pihak internal yaitu dukungan dari ketua yayasan untuk setiap program yang dijalankan, semua pendidik dan tenaga kependidikan di KB-TK AlFalah yang bekerja keras dalam mensukseskan kegiatan-kegiatan disekolah, tersedianya dana yang mencukupi, tersedianya sarana dan prasarana yang memadai yang dimiliki sekolah. Pihak eksternal yaitu adanya dukungan dari pihak orang tua, masyarakat sekitar terhadap kegiatan yang dilakukan sekolah sehingga mereka mau memberikan partisipasinya dalam pelaksanaan program sekolah. Adapun faktor penghambatnya antara lain kesibukan dari pihak orang tua murid dan pihak instansi yang diundang oleh sekolah, adanya tipe masyarakat yang berbeda-beda, serta birokrasi yang sulit untuk setiap instansi yang dituju untuk mengisi kegiatan di sekolah, dan (4) upaya mengatasi hambatan yang timbul dalam partisipasi masyarakat yaitu antara pihak sekolah harus berkoordinasi dengan pihak orang tua menentukan waktu yang pas untuk pelaksanaan kegiatan, pihak sekolah memberdayakan organisasi Persatuan Orang Tua Murid (POM) untuk memberikan motivasi dan pengertian kepada orang tua lain yang kurang berperan aktif dalam mendukung pelaksanaan program sekolah, pihak sekolah mencari pemateri lain yang lebih mudah diajak bekerja sama, serta para ustadzah bisa melakukan simulasi sendiri sesuai dengan kegiatan yang akan dilakukan.

\section{Saran}

Saran yang bisa diberikan peneliti dari hasil penelitian yang dilakukan yaitu: (1) kepala KB-TK Al-Falah Batu diharapkan dapat mengikutsertakan masyarakat tidak hanya dalam perencanaan dan pelaksanaan saja, tetapi dalam hal evaluasi program pendidikan sehingga dapat memperoleh saran dan masukan terhadap program yang sudah dijalankan, (2) orang tua murid diharapkan dapat berperan aktif dalam mendukung pelaksanaan program sekolah. Selain itu POM diharapkan bisa mengajak orang tua yang kurang berperan aktif untuk ikut serta membantu kegiatan sekolah sehingga semua orang tua murid juga dapat terlibat dalam mendukung pelaksanaan program kegiatan di sekolah, (3) masyarakat diharapkan dapat memberikan saran dan masukan terhadap program kegiatan yang dilaksanakan untuk memajukan penyelenggaraan pendidikan disekolah, dan (4) peneliti lain diharapkan dapat mengkaji lebih dalam tentang teknik peningkatan partisipasi masyarakat dalam 
mendukung penyelenggaraan pendidikan di sekolah sehingga dapat memberikan referensi dan informasi yang dapat memaksimalkan hasil penelitian sebelumnya.

\section{DAFTAR RUJUKAN}

Benjamin Y.M and Chui, H.S. 1997. Parental Participation in school Councils in Victoria, Australia, International Journal of Education Management,11(3):hlm.102:110,(Online),(http:// www.emeraldinsight.com/doi/pdfplus/10.1108/ eb009604), Diakses 24 Februari 2016.

Maisyaroh. 2001. Maksimalisasi Peran Masyarakat dalam Penyelenggaraan Pendidikan: Suatu Kajian Menyongsong Otonomi Pendidikan. Jurnal Pendidikan, 14 (2): 110-117.
Moleong, L. J. 2012. Metode Penelitian Kualitatif. Bandung: Remaja Rosdakarya.

Mustiningsih. 2009. Psikologi Pendidikan (Buku Ajar). Malang: Universitas Negeri Malang.

Shun Wing Ng. 2013. Including parents in school governance: rhetoric or reality, International Journal of Educational Management, Vol. 27 Issue: 6, hal.667-680, https://doi.org/10.1108/ IJEM-07-2012-0087 Diakses 2 April 2016.

Pidarta, M. 1998. Manajemen Pendidikan Indonesia. Jakarta: BumiAksara.

Sumarto, H SJ. 2004. Inovasi, Partisipasi dan Good Governance. Jakarta: Yayasan Obor Indonesia.

Triwiyanto, T., Kusumaningrum, D.E. 2015. Important Reasons and Effort to Build School Work and Committee Harmony. Acta Scientiae et Intellectus. 1 (4): 5-13. 